\title{
Too Far Gone: The Psychological Games of Cormac McCarthy's All the Pretty Horses
}

\section{Michael Wainwright}

\section{(2) OpenEdition \\ Journals}

Electronic version

URL: https://journals.openedition.org/ejas/11630

DOI: 10.4000/ejas. 11630

ISSN: 1991-9336

Publisher

European Association for American Studies

\section{Electronic reference}

Michael Wainwright, "Too Far Gone: The Psychological Games of Cormac McCarthy's All the Pretty Horses", European journal of American studies [Online], 11-2 | 2016, document 13, Online since 11 August 2016, connection on 08 July 2021. URL: http://journals.openedition.org/ejas/11630 ; DOI: https://doi.org/10.4000/ejas. 11630

This text was automatically generated on 8 July 2021.

Creative Commons License 


\title{
Too Far Gone: The Psychological Games of Cormac McCarthy's All the Pretty Horses
}

\author{
Michael Wainwright
}

\begin{abstract}
A boundary is not that at which something stops
but, as the Greeks recognized, the boundary is that from which something begins its presencing. Martin Heidegger, "Building, Dwelling, Thinking"
\end{abstract}

"If I dont go will you go anyways?" Lacey Rawlins asks his friend John Grady Cole, the protagonist in the first part of Cormac McCarthy's (1933- ) Border Trilogy, All the Pretty Horses (1992), concerning their proposed relocation to Mexico. "I'm already gone" (27), replies Cole, unconsciously but succinctly testifying to his own mental state. The sixteen-year-old Cole, in response to the necessities occasioned by his maternal grandfather's death-an event that will leave him homeless after the sale of the deceased man's ranch-is projecting part of himself, deracinating a certain element of desire, and transforming the psychological thread attached to that element into a guiding clew. This anticipated escape from the broken nuclear family of Cole's upbringing reiterates at a later stage of psychological maturation and in another guise an unresolved tension of his psychical infancy. Cole's projected departure from home hereby appeals to a psychoanalytical interpretation, and this critical approach helps to establish and elucidate the psychological depths of McCarthy's novel. Specifically, the formative "fort-da" ("gone-there") game, which Sigmund Freud (1856-1939) defines in Beyond the Pleasure Principle (1920), and which Jacques Lacan (1901-1981) emends in reconsidering the psychoanalytical subject (or \$), slowly emerges as a revelatory means for analyzing John Grady Cole both as a victim of maternal absence and as a representative of a passing cultural phenomenon, the American cowboy.

Numerous critics of McCarthy's oeuvre, including Edwin T. Arnold and Jay Ellis, have read his works from a Freudian perspective, yet few have analyzed a single work from the more hazardous but proportionally more rewarding vantage point of Lacanian 
psychoanalysis. ${ }^{1}$ Nell Sullivan's prolegomenon on the paradoxical pleasure of jouissance is the most notable exception to this reluctance, but while the psychoanalytical insights Lacan gleaned from his dialogue with Freud's conceptualizations require a painstaking appraisal, the restricted space afforded Sullivan by A Reader's Companion to Cormac McCarthy (1995) denies her adequate analytical license. ${ }^{2}$ In contrast, the following article answers the Lacanian demand for hermeneutical care, not so much psychoanalyzing All the Pretty Horses, as revealing the psychoanalytical prescience of McCarthy's text. It is perhaps appropriate, therefore, that this critical furtherance, which contributes specifically to McCarthy studies and generally to the application of Lacanian theories to literary studies, concerns at once a form of absence and the insatiate need to fill that void.

The nascent individual gradually answering his subjective absence in the fort-da thesis of Beyond the Pleasure Principle is Freud's eighteen-month-old grandson. This "good boy," who neither disturbed his parents at night nor misbehaved in general, was especially attached to his mother, "who had not only fed him herself but had also looked after him without any outside help" (8). Only the child's habit of picking up small objects and casting them away, an exercise he accompanied with the word fort (or gone), perturbed his mother. Indeed, the infant's enthusiasm for this activity developed to the point where retrieving the jettisoned items became somewhat onerous. Having repeatedly witnessed the boy's behavior, Freud concluded, "it was a game": the sole use the infant made of these items "was to play 'gone' with them." A particular observation supported this hypothesis. "The child had a wooden reel with a piece of string tied round it," recounts Freud. "It never occurred to him to pull it along the floor behind him, for instance, and play at its being a carriage. What he did," as Freud recalls, "was to hold the reel by the string and very skilfully throw it over the edge of his curtained cot, so that it disappeared into it, at the same time uttering his expressive fort. He then pulled the reel out of the cot again by the string and hailed its reappearance with a joyful $d a$ ['there']. This, then," states Freud, "was the complete game-disappearance and return" (9).

Freud's initial interpretation of this ludic function relates to his grandson's achievement in social terms: the child repudiated the instinctual satisfaction gained from not protesting his mother's absence; this self-discipline exemplified a libidinal renunciation for which the fort-da exercise provided recompense. On reflection, however, this explanation dissatisfies Freud. "The child cannot possibly have felt his mother's departure as something agreeable or even indifferent. How then," asks Freud, "does his repetition of this distressing experience as a game fit in with the pleasure principle?" (9). The answer to this question lies in the boy's passive situation when his mother absented herself. At first, his nascent awareness of her departure overpowered him, reasons Freud, but by simulating the act of maternal departure in the form of a game, the child became an active participant in his own dilemma. "These efforts," thinks Freud, "might be put down to an instinct for mastery that was acting independently of whether the memory was in itself pleasurable or not." Notwithstanding the logic of this deduction, Freud rejects this thesis too, submitting two alternative explanations in which the second subordinates the first: the child mastered an unpleasant situation with his fort-da game and the amusement afforded by this exercise expressed his revenge. "Throwing away the object so that it was 'gone,"' posits Freud, "might satisfy an impulse of the child's, which was suppressed in his actual life, to revenge himself on his mother for going away from him" (10). Thus, 
the fort-da game has "a defiant meaning: 'All right, then, go away! I don't need you. I'm sending you away myself"' (10); the ludic function actualizes a step on the psychological road to personal identity and independence.

The parallel I am drawing between Freud's eighteen-month-old grandson, as a housebound infant, and McCarthy's John Grady Cole, as a prospective emigrant from his motherland, implies that the teenage Cole is expostulating, "All right, America, don't mother me (you no longer embody my beliefs, ideals, and practices). I don't need you. I am leaving you for a surrogate mother, one who meets my needs and expectations: Mexico." The age difference between the two subjects may seem to argue against my analogy, but disruption of an infantile phase of psychological maturation leaves a legacy that remains active into adult life. Moreover, sociohistorical factors pertain to the unconscious in significant ways, and Freud's explanation of the fort-da game, which overly relies on the paradigm of the nuclear family, actually works in favor of this interpretational analogy. A nascent subject within Freud's favored social structure faces two opposed but interlinked demands: he must not only find satisfaction in a single parent, his mother, but also gain that fulfillment despite the repression demanded by orthodox family relations.

Although John Grady Cole was born in 1933, when the nuclear family was the standard American kindred structure, McCarthy offers a different scenario in All the Pretty Horses, a scenario that anticipates postwar alterations to the environment formative of attachment behavior. Hence, in terms of a literary hermeneutic, the dissolution of the nuclear family severely complicates the equivalence between the Freudian infant and the infant Cole; instead of Cole's behavior taxing maternal devotion, his mother's actions sow the troubled seeds of her son's psychological maturation. "We were married ten years before the war come along," Cole's father latterly tells his son. "She was gone from the time you were six months old till you were about three. I know you know somethin about that and it was a mistake not to of told you. We separated. She was in California" (25). That neither Cole nor his father ever uses the Christian name of Cole's mother implies the psychological blanking that accompanies the compromised development of the boy's subjectivity. Ordinarily, cowboy culture operates according to a sexual division of labor, which expects women to superintend the space of domesticity, providing the physical and emotional background that not only supports men's economic labors outside the home, but also supplies and nurtures the laborers (both male and female) of the future. For the nascent subject, these social relations foreground the maternal while obscuring the paternal presence, a gendered asymmetry that the father's demands on the mother slowly begin to rebalance. Cole's mother, however, upsets these standard structures. A double loss informs the nascent subject and this twofold absence necessitates a psychological treatment of McCarthy's protagonist in All the Pretty Horses. The novel cannot but follow the lead of John Grady Cole's unconscious.

For, unlike the Freudian case, the departure from Texas of Cole's mother signals not minutes, nor hours, but years of maternal absence. She does not nurture her son and disregards the expectations of maternal responsibility; in consequence, two female house servants, Luisa and her mother Abuela, must tend John Grady. "Luisa looked after you," confirms Cole's father. "Her and Abuela" (25). In Freud's nuclear family, the mother tends her child "without any outside help" (8), but the infant Cole relies on two surrogates. "Una abuela" translates from Spanish into English as "a grandmother," making Abuela's Luisa, in effect, "a mother." These familiar names for blood relations 
belie the fact that the two women's attendance on the infant Cole, which cannot help but present a shifting female image, is unfamiliar in kindred terms. The cues of kinrelated recognition, which Cole's father provides on the paternal side, remain barely exercised in their maternal register. In short, his mother's fleeting presence followed by her long-term absence traumatizes Cole's developing psyche. That he will forever withhold his mother's Christian name, as a conditional secret respected by his father, expresses through silence his devastating attachment to her absence. Lacan's emendation of Freudian fort-da theory, which reemphasizes the basic paradigm, but without recourse to Freud's methodological sleights of hand, helps to interrogate McCarthy's skill in delineating this form of psychological disturbance.

The first of Freud's prestidigitations involves his data collection. Freud gathered much of his fort-da evidence "not from the episode itself," chronicles John Brenkman, "but from the boy's behavior a year later" (148). The second sleight of hand, as Brenkman observes, concerns Freud's interpretation of the libidinal content of the fortda exercise, which "clearly derives from the observations made between the time the child was three-and-a-half and nearly six" (149). Adducing his overall analysis axiomatically from a later stage of psychical development is Freud's third prestidigitation. Thus, the Oedipus complex, weighing in favor of the maturing boy's desire for revenge, erroneously influences Freud's interpretation of an earlier stage of psychical development.

In contrast, Lacan does not deny the incidence and importance of fort-da behavior as a normal part of psychological maturation, but reinterprets this game in interrelational terms: the nascent subject traverses two successive domains, the "real" and the "imaginary," before the ludic function draws him into the "symbolic" realm of language. In the neonatal state of the real, maintains Lacan, the infant is a non-subject unable to distinguish between himself and the "Other" that satisfies his requirements. His "first status as an infant," Éric Laurent explains, "is to be a lost part of that Other" ("Alienation and Separation [II]" 30). The real is the easiest stage of psychical development to define but the most difficult to describe. In a sense, one cannot talk about the real; any such discussion is impossible. The moment the real becomes an object of discourse, its description by symbolic components (individuals and language) negate its existence. One can only study the real in its effects on the imaginary, which is the prelinguistic phase of subjective coalescence, and on the symbolic, which grounds the subject in society. Nonetheless, "as Lacan argues in many different contexts," and as Brenkman emphasizes, "a child's dependence on its mother is a dependence on her love" (146). She is the nascent subject's all-powerful Other.

That the psychological limbo of prenatal existence lasts for approximately six months, and that his mother deserts Cole when he is "six months old" (25), are therefore significant details in All the Pretty Horses. Her abandonment of Cole, when she simply "left out of here" (25), imposes on her child a psychical separation from the maternal Other, not as a gradual ontogenetic process, but as a sharp transition dictated from beyond rather than from within the prospective subject. Cole's delightful freedom of non-presence in the presence of his mother is dramatically curtailed and only the attenuated succor of Luisa and Abuela as substitute mothers accompanies his separation from the maternal Other. This unsatisfactory state of affairs is the "tuché," or Lacanian trauma, which accompanies Cole's transition into the imaginary. 
The self-awareness that arises in the imaginary, an ability that Lacan designates as "mirror imaging," emanates from an evolutionarily fostered fascination with aesthetic form. This developmental phase, in which the infant becomes aware of himself as a fractured collection of parts that are distinct from their surroundings and thereafter slowly learns to appreciate his body as a single unit of interconnected parts, lasts for approximately twelve months. Confronted by his mirror image not only in the specular glass, but also in the movements of other people, and especially in his mother's actions, the baby eventually recognizes the self-enclosed nature of human physiology. For Cole, the nascent self-awareness suggested by his appearance at the opening of the novel is at once restricted and distorted. The image Cole first presents to the reader, which occurs as he enters his grandfather's homestead to pay his respects over the dead man's body, is a form of projection. Whereas "the candleflame and the image of the candleflame caught in the pierglass twisted and righted when he entered," the "black suit[ed]" Cole "stood in the dark glass," as if trapped within the reflective process of mourning as unfulfilled self-enlightenment. Moreover, the rigor mortis both of his grandfather's dead body and in "the portraits of forebears only dimly known to him all framed in glass and dimly lit above the narrow wainscoting" of the hallway repay the young Cole's obsequies (3; emphasis added). Cole is "initially framed by reflecting glass" (36), as Stephen Tatum notes, but this Lacanian mirroring within a frame amounts to more than Tatum's motif of "reflections" that "cast shadows" (35). To varying extents, every mature subject's relation to society is analogous to that nascent subject's interaction with his mirror image, because the emerging subject's situation relates to an unattainable ideal. The pall of shadowing in this scene, therefore, connotes two images of perfection beyond Cole's reach: his mother and his cowboy heritage.

Notwithstanding the identification of mirror imaging, the emerging subject does not realize his capacity for independent action at this time-the self-sufficiency of reflected forms goes unnoticed. "Self-identity is thereby caught in the conflict between the experience of an uncoordinated body invested with needs, affects, and unmastered movements," as Brenkman explains, "and an imaginary body that forms the core of the subject's ego. At the same time, this experience marks the original split in the subject's relation to the body; the erotogenic body is divided from the body image" (156). Reflected in his grandfather's corpse, as in a mirror darkly, is the imaginary body of the black-suited Cole. Enlightenment dawns on Cole, but this is the dark, negative, or absent knowledge that death "was not sleeping. That was not sleeping" (4).

Significantly, as one can surmise from Cole's tendency to avoid his specular image, the curtailment of delightful freedom in his mother's presence-the suddenness and completeness of which the shifting attendance of his Mexican surrogates only accentuated-dominated his transition through the imaginary. His mother's withdrawal from the home was formative of Cole's fractured self-awareness. His Mexican lover, Alejandra Rocha, will briefly inspire Cole with the hope of resetting these psychological shards. "Such harborage," as Terrell L. Tebbetts points out, "would make him no longer a wanderer over the surface of the earth but a man rooted in it" (51). Hence, on the one occasion when the teenage Cole does contemplate himself in a mirror, which occurs after a drunken fight in response to his permanent split from Alejandra, a self-apprehending gaze confirms Cole's personal sense of shattered subjectivity. Inaugurated over fifteen years earlier, as the hazy condition of the glass adumbrates, the unmistakable signs emanating from his mother's initial absence 
persist. Maternal absence, implies All the Pretty Horses, both impels Cole's self-scrutiny and confirms his self-focused expectations. Cole does not see anything other than his fractured self: "He studied his face in a clouded glass. His jaw was bruised and swollen. If he moved his head in the mirror to a certain place he could restore some symmetry to the two sides of his face and the pain was tolerable if he kept his mouth shut" (255). He can only stand and endure this painful reconfirmation.

According to Lacan, self-imagery makes identification and recognition a separate, or distanced, fiction that guides the efforts of the infant toward autonomy. These attempts elicit a specific form of joy, or Lacanian jouissance, when the nascent subject both identifies with his reflected image and recognizes his control over that image. Even so, insists Lacan, the maternal Other is the locus in which subjective characteristics become present, with the mother the ultimate selector and articulator of her child's jouissance. Paradoxically, while a feeling of articulated control replaces the infant subject's sense of fractured self, any attendant feelings of independence are an illusion because the infant remains wholly dependent on his mother.

Conversely, as "the real substance at stake for jouissance" (Laurent, "Alienation and Separation [II]" 31), the child is constitutive of the maternal Other's desire. The infant Cole, as a part of his mother's jouissance, was an obstruction to her own desire. This obstacle presented the threat of aphanisis, which Ernest Jones (writing in Freud's shadow and prefiguring Lacan) defines in the "Early Development of Female Sexuality" (1927) as "the total, and of course permanent, extinction of the capacity (including the opportunity) for sexual enjoyment." Aphanisis, insists Jones, is "the fundamental fear which lies at the basis of all neuroses" (23). In McCarthy's novel, Cole's mother did not want the restrictions of married motherhood, which her own mother's position in the paternal homestead had prefigured. Instead of the cares and responsibilities that attend the role of the maternal Other, she desires the freedoms of single womanhood. Cole is her only child, and her divorce from his father is final before her own father's death. Subsequently, her stage career, on the one hand, and the men that attend her, on the other hand, signify her release from familial and social expectations. That she is an actress, someone who defers to a playwright's artistic practice, is rather ironic: her freedom is as illusory, or fictional, as the roles she plays on stage. In effect, her career puts a psychological impediment on display.

In Lacanian terms, the human self comes into being through a fundamentally aesthetic type of recognition and, as the separation involved in mirror imaging suggests, complete unity of selfhood is unattainable. The partial coalescence of identity results from the identification of the self with a false image of that self. This imaginary Other prescribes a yearning in adulthood for the omniscience of articulated control so fleetingly experienced during mirror imaging. Put simply, what is commonly called "the self" is not the self at all but an imaginary (or illusory) Other, which Lacan calls the "specular I." Nevertheless, that mirror imaging replaces the feeling of physical inarticulation with an awareness of physiological self-expression indicates that the maturing infant is receptive to articulated systems; as a result, semiotic manifestations come within the purlieu of the developing subject.

Lacan appropriates Freud's account of his grandson's actions with a cotton reel to trace this stage in psychological maturation. The fort-da game, which responds to the lengthening absences of the maternal Other that accompany the child's development, and which signals the transition from the imaginary to the symbolic, is a phenomenon 
of both consciousness and linguistics: this behavior does not so much express the subject's wish for revenge as the desire for situational interactions that will acquaint that subject with the symbolic. "Need matures into Desire via recognition from the Other" (73-74), as Ellie Ragland-Sullivan states, and "Desire," as James M. Mellard notes, "is imaged by Lacan as the "dérive de la jouissance" (121). Paternal authority now comes into play. The father uses language to call the mother, which takes her away from their child and the tasks of motherhood, and the developing subject begins to notice the recurring nature of these summonses. In All the Pretty Horses, two sources of male symbolic usage-neither of which Cole's father provides-tempt Cole's mother away from her son: the words of playwrights-the majority of whom are men-and those of her lovers. In the first case, "looking for some point of connection," relates Tebbetts, Cole "hitchhikes to San Antonio through a long and bitter winter day to see his mother in her play. He hopes to grasp her world, what it is to her." Their two domains, however, as Tebbetts implies, are mirror images: "she has seen nothing in the ranch, while he loves it; he sees nothing in the play, while she loves it" (40). To one enamored of the stage, or the theatrics of an indoor space, the geographical expanse of a cowboy ranch remains untenable. To one inculcated by cowboy culture, or man's ecological environing of outdoor spaces, the strict delimitations imposed by the proscenium arch elicit little interest.

Thus, men other than her husband keep Cole's mother from him, and the absence enforced by these Others significantly exceeds the brief departures normally occasioned by the man who shares a home with his wife and son. In Lacanian terms, the absences caused by the male use of language inscribe a trace of "specific castration" in the psyche of the maturing subject. Repeated occasions of calling the maternal Other away from her charge imply that the mother is "not-all." She represents a lack related to sexual difference, but this absence is symbolic rather than biological, with the signifier that names this female lack being the Lacanian "phallus." The phallus is the privileged signifier that dominates the symbolic and determines the meanings of other signifiers. Through the process of language, humans discover and learn to accept the symbolic order by repressing what is unacceptable to orthodox standards. Vestigial desire for the real and the joy associated with imaginary mastery become the unconscious part of the psyche. In this way, an individual becomes a fit member of society-what Lacanian terms the "social I." For Cole, however, attempts to expand the significance of his fort-da game fall foul of interactions and relationships that confirm the initial trauma inflicted by that exercise: his mother's two-and-a-half-year maternal absence encapsulates not only his transition into the imaginary, but also his shift into the symbolic.

The genesis, dynamics, and relays of the fort-da game instantiate a formative subject's first interpersonal relationship. Hence, the fort-daexercise at once reveals the prospect of intersubjectivity and introduces the subject to language. "The game," avers Brenkman, "is an appeal to, an opening onto, a leap toward interactions which the situational context of the child's experience does not immediately provide"; as with the later Oedipus complex,the fort-da exercise is a dialectical rite of passage "between the self-activity of speaking-playing and the institutionally constrained discourses and interactions in the situation itself" (150). Freud, although guilty of methodological sleights of hand, was correct in attributing significance to actions that combine occultation (as in the cotton reel disappearing from his grandson's sight) with the conjugation of the phonemes fort and $d a$. "No one would dispute that Freud was 
right," states Lacan in "The Direction of the Treatment and the Principles of its Power" (1958), "to translate" his grandson's behavior "immediately by the Fort! Da! of the German he as an adult spoke." Even so, maintains Lacan, "phonetic perfection is less important than phonemic distinction" (497). By entering the linguistic system, the subject begins to assimilate a structure of differences, but must do so in medias res. This absorption is necessary for the child's development into a functioning member of society, and the world of signs, as a domain characterized by long-standing antinomies, awaits that subject with a predetermined position.

In the context of the nuclear family, these binary oppositions include father/ mother, husband/wife, male/female, brother/sister, mother/son, father/daughter, mother/ daughter, and father/son. Lacan's famous S/s (or Signifier/signified) of urinary segregation, which inverts Ferdinand de Saussure's definition of the sign as Signified/signifier, underscores this point. Signs that differentiate between washrooms according to gender-"Ladies" and "Gentlemen"-need not denote a difference in signifieds, asserts Lacan in "The Agency of the Letter in the Unconscious, or Reason since Freud" (1957): the water closet for women and men might be separate rooms but can be conceptually identical. In this instance, visual signifiers $S_{1}$ and $S_{2}$ do not denote distinguishable signifieds $\mathrm{s}_{1}$ and $\mathrm{s}_{2}$; rather, $\mathrm{S}_{1}$ and $\mathrm{S}_{2}$ state and confirm orthodox attitudes toward sexual difference. Put succinctly, signifiers tell subjects where to go and into which segregational category they fit, with Lacan's reversal of Saussurean precedence emphasizing the Lacanian contention that signifiers hold primacy over signifieds. The maternal Other relays not only the first of these signifiers-initially she is the child's exclusive language provider-but also a wider sense of otherness to the maturing subject-language is a form of communal expression. The mother dominates her infant's imaginary domain and oversees (or referees) her child's fort-da game; as Brenkman points out, "her exclusive discourse defines her 'omnipotence"' (146).

In Cole's case, the non-presence of the maternal other during mirror imaging anticipates the master signifier of maternal absence during his fort-da exercise, and his mother's return to the family approximately eighteen months into the third and final Lacanian phase of her son's psychological maturation corroborates his primary acknowledgment of his mother's nonpresence. She is too late to heal Cole's tuché and her reappearance merely exacerbates his unresolved fort-da tension. "Even when they are together," Tebbetts observes, "they are apart" (40). Unsurprisingly, a lack of maternal bonding during childhood has instilled in Cole both a precocious awareness of the illusory dimension of human autonomy and a pronounced lack of linguistic articulation. "You dont talk much," observes a truck driver who picks up the hitchhiking teenager. "Not a whole lot" (19), replies the mutedly grateful hiker, before relapsing into silence. Cole's bilingualism testifies to the presence during his infancy of an American father and Mexican surrogate mothers, while his reticence bears witness to his formative tuché. The need to heal this scar-a pressure that overemphasizes the "not-all" of womanhood-becomes the unconscious impetus behind Cole's desire for jouissance.

Cole's father unconsciously helps to transcribe his son's anxiety onto a related plane by teaching him chess. This ludic translation serves Cole's unappeased appetite for deracinating a certain element of desire, with chess supplying a repetitive substitute for formative fort-da situations. "Whatever in repetition is varied," asserts Lacan in The Four Fundamentals of Psycho-Analysis (1977), "is merely alienation of its 
meaning. The adult, and even the more advanced child, demands something new in his activities, in his games. But this 'sliding-away' (glissement) conceals what is the true secret of the ludic, namely, the most radical diversity constituted by repetition in itself" (61). The fort-da game exhibits this glissement. The formative subject manifests itself, argues Lacan,

as an insistence that the story should always be the same, that its recounted realization should be ritualized, that is to say, textually the same. This requirement of a distinct consistency in the details of its telling signifies that the realization of the signifier will never be able to be careful enough in its memorization to succeed in designating the primacy of the significance as such. To develop it by varying the significations is, therefore, it would seem, to elude it. This variation makes one forget the aim of the significance by transforming its act into a game, and giving it certain outlets that go some way to satisfying the pleasure principle. (61-62).

The fort-da exercise repeatsthe tuché of the mother's departure, but is not identical with that trauma; rather, this repetition entails something radically different. "The fort-da game, then, opens a field of playing and speaking," as Brenkman states, "which can develop various permutations and transformations. There is no reason to assume that the game, however much it takes its significance from repetition, does not also contain the possibility of new uses, elaborations, applications" (147).

In All the Pretty Horses, the game of chess, as an iterative source of radical difference, becomes one means by which John Grady Cole temporarily satisfies his need for jouissance. Chess exemplifies a markedly different class of pastime from many kinds of recreation because tactical problems of complete information that exclude chance are not games in the usual sense. "Chess is a well-defined form of computation," as John von Neumann-the father of game theory-once explained to Jacob Bronowski. "You may not be able to work out the answers, but in theory there must be a solution; a right procedure in any position" (324). Every contingency in chess is open to tabulation. The permutations of the game, which rely on projecting various pieces into the territory shared by one's opponent, as if jettisoning objects to elicit responses from a particular Other, provide an elaborate set of fort-da variations.

Cole plays chess against his father until the age of eight. Then, in a parallel to his mother's absence, Cole's father leaves home. He must serve overseas in WWII and his son's major ludic outlet is frustrated. The translation of chess from a fort-da to an Oedipal situation, which would see Cole gain enough experience to beat his father over the chessboard, is indefinitely deferred because Cole Senior's ordeals as a prisoner of war deplete his mental reserves and, on his return from the East, he has only "the patience to play poker" (11). This recreation soon turns into a kind of a vocation. The remains of his acumen enable Cole Senior to lose himself in the adrenalin surge of semiprofessional gambling rather than the shattered memories of war. On one occasion, John Grady offers to "bring the chessboard" (11) to his father's hotel room, but Cole Senior is not interested. This denial breaks a gaming provenance handed down from father to son and represents a newly severed family tie.

As a result, John Grady opens his ludic faculty to another form of play, with life on his maternal grandfather's ranch offering him a role, or Lacanian "fantasy," which not only feeds his lack of jouissance, but also satisfies his desire for independence. This formative vocation also proffers Cole an unconventional mirror. "The souls of horses," as the old "mozo" (110) Luis will later tell him, "mirror the souls of men" (111), and Cole learns to appreciate equine companionship. Horses become a matter of both 
metaphysical mirroring-somewhat making up in a spiritual way for his shattered mirror imaging as an infant-and corporeal blood consciousness. Unfortunately, with the death of his grandfather, which allies the passing of cowboy culture with a previous social extinction, the demise of the Comanche as a "nation" (5), Cole's patrilineage hands him another "bum deal." Ostensible power over Cole's future-in what John G. Cawelti calls "a depressed West Texas in the immediate aftermath of World War II" (115)-passes to his mother. As inheritrix, his now "all-powerful" mother tries to force Cole's psychological hand, pressurizing him to enter college. She desires his selfidentification with the signifier "student" instead of "cowboy." Postwar economics supports this shift in designation. Cole disagrees, but she demands that he "go to school." Commonsense supports her suggestion: "You cant run a ranch," she insists, "you're sixteen years old" (15). From the Freudian fort-da perspective, a cowboy in his mother's judgment is a "bad boy," while a student is a "good boy."

This attempt at enforced signification has a Lacanian dimension. While Cole identifies with one signifier $\left(s_{1}\right)$, his mother affixes a different signifier $\left(s_{2}\right)$ to him. His mother's ideal will impinge on Cole throughout his life, with alienation insisting on the preeminence of that designation. "At the very moment at which the subject identifies with such a signifier, he is petrified," explains Laurent. "He is defined as if he were dead, or as if he were lacking the living part of his being that contains his jouissance" ("Alienation and Separation [I]" 25). His mother's attempt to replace her son's fantasy threatens to remove the jouissance from Cole's life. That Cole catches sight of his mother in the Menger Hotel, San Antonio, after her evening stage performance, on the arm of an unrecognized man, and that the receptionist finds "no Cole" (22) in the hotel register confirm that his mother has shed her role as John Grady's source of maternal pleasure.

Although alienated from the maternal Other via the superimposition of "student" over "cowboy," this dominant signifier does not totally define Cole; in consequence, he falls back on the identification tentatively formed during mirror imaging. He unconsciously addresses his need for jouissance through the signifiers "Luisa" and "Abuela" and the trace of their shifting referential presence. This combination of substitutes posits the deracination of Cole's jouissance from his primary motherland, Texas, and its replanting in the motherland of his surrogates, Mexico. The adolescent Cole's "gone," which echoes the "fort" of Freud's grandson, relates to Mexico, while his "there," to complete the psychoanalytical schema with a "da," relates to Texas. In Lacanian terms, Cole's "I'm already gone" (27) is a subjective expression: "it is a small part of the subject that detaches itself from him while still remaining his, still retained" (62). This urge for psychical relocation is of a chronotopic order, being both spatial and temporal, with the space demarcated by Mexico supposedly offering Cole an autochthonic, less "civilized," more "natural," and therefore wholesome, or unitary, environment.

"Rocked in his saddle," as Dianne C. Luce's metaphor suggests of the horse riding Cole, "this dreaming infant ventures into an alien land" (61). As if on a rocking horse, the teenage John Grady immigrates to Mexico in a play for jouissance, as Lacan's emendation of Freud's fort-da analysis substantiates. The cotton-reel is not so much symbolic of the mother as synecdochic of the nascent subject. The baby, attached as he is to the reel via the thread he holds, experiences a psychological form of selfmutilation. This savage projection, which signals a break from the imaginary, starts to 
put the order of significance into perspective. The emerging subject detaches a part of himself in response to what the mother's absence has created on the frontier of his domain. The reel, which in Lacanian guise manifests the petit object a (autre), is the subject's formative part. Hence, the fort-da game repeatedly manifests a Spaltung (or division of the subject). Mexico is "the other South," el otro sud, of which Ann FisherWirth writes with reference to McCarthy's canon: "not the place one is born but the place the stringent longings of one's imagination make one come to" (115; emphases added).

Freud's notion of Spaltung is an intersystemic one, which gives rise to the ego-id division. In the process of splitting, as Joël Dor explains, "the subject may be cut off from a part of his psychic contents through the action of repression." In contrast, Lacan's understanding of Spaltung is "plurisystemic," and "proceeds from the subject's own subjection to a third order, the symbolic" (129). "Lacan argues," as RaglandSullivan observes, "that language is driven by an excess in jouissance itself, denoted by object $a$. Insofar as the three forms of jouissance-of meaning (the symbolic), body (the imaginary), and the physiological organism (the real) -all seek to maintain consistency (i.e., to close out the conflicts of the real that disrupt the conscious illusion that the body, being, and language work in harmony with one another)," states RaglandSullivan, "object a marks a limit point" (188). The fort-da game for Lacan represents a splitting of the object of desire. Spaltung is therefore a defense mechanism that divides an anxiety-provoking referent into a good part and a bad part.

Cole's prorogated answer to the formidable psychological perimeter created around his formative subjectivity by his mother's prolonged (and now irrevocable) absence is to cross that perimeter during adolescence. Spatial dissection into a hospitable portion (the land of Cole's prospects) and a hostile portion (the land of Cole's prememories and memories) characterizes his teenage behavior. Cole leaves America behind as the motherland that has changed beyond recognition (personified by the different roles his mother plays on the stage) and that has forged loyalties with Other parties (his mother's attachment to lovers other than her husband). The teenager posits Mexico as his welcoming, comforting, and revivifying motherland. Mexico is the nostalgic replacement for the lack inspired by his original but disloyal mother. In semiotic terms, the signified (or mental construct) of a motherland never alters for Cole, but the corresponding referent changes from America to Mexico, as the attendant signifier attests.

This strategy, as All the Pretty Horses explores, fits with the sociohistorical sense that cowboys no longer fit seamlessly into the American cultural landscape. The postwar cowboy-a nonconformist of the Truman and Eisenhower years, but one whose countercultural identity was being usurped by a new generation of peripatetic nonconformists, the type of men immortalized in Jack Kerouac's On the Road (1957)was becoming isolated, as James Bowman argues, "in being entirely idiosyncratic" (186). "How the hell do they expect a man to ride a horse in this country?" complains Rawlins on encountering another barbed wire fence on their ride toward the Mexican border. "They dont," is Cole's simple but knowing reply (31). On the one hand, as John Blair argues, "Texas has become the United States in its larger, undifferentiated sense, a place where history is no more than the moment, where everything is new and everything is relative" (301). On the other hand, as the metal barbs strung along these Texan fences imply, the cowboy is no longer welcome in a cultural landscape that used to be his own. 
That Cole, Rawlins, and Jimmy Blevins (the preteen runaway who dogs their steps before joining them) undertake their journey south using equine rather than automotive horsepower symbolizes their rejection of this cultural shift. These horses stand out against a background of American industrialization as an anachronistic means of transport,but supposedly help their riders merge into the apparently natural and authentic context provided by Mexico. Such an interpretation supports the first part of Vereen Bell's thesis concerning All the Pretty Horses, which understands Cole's aim as a desire to "move back in history," but not the second part of Bell's proposal, which somewhat confusingly suggests that Cole also aims for "a place outside of time" (926). John Grady Cole, like the biblical figure with whom he shares the initials JC, banishes himself from his motherland. Cole's exile takes him into what many of his American contemporaries would deem the wilderness of South America. Nonetheless, wherever Cole travels, and whatever his adventures produce in the way of experiences, an anachronistic quality accompanies him. Nancy Kreml cites McCarthy's "use of rare and arcane vocabulary" in this regard. Words such as "espaliered" (73) and "isinglass" (242) are not "old or rare enough to be marked as archaic in common dictionaries, yet the reader recognizes them as rarely occurring in common speech" (47). By explicitly italicizing these instances of arcane language, McCarthy marks their distance from the phatic ease of a common mother tongue-and this tendency toward linguistic alienation from the self attends Cole throughout the novel.

Cole still requires a maternal substitute, however, and believes that ranching in Mexico will supply that need. At a fundamental level, Cole's translocation is an attempt to reassign a calming correspondence between the signifier and signified of the stable and comforting sign connotative of his original formative territory, the womb. This wakening dream of prenatal utopia calls on Cole's desire; as a result, his passage across the river that separates Mexico from the USA has that Heideggerian sense "from which something begins its presencing" (152). They rode across the river "naked" and on the far bank they "turned and looked back at the country they'd left. No one spoke" (45). This river acts as a division between two cultures, cultures that share certain elements, but in which one language (English or Spanish) dominates the other (Spanish or English). In The Pleasure of the Text (1973), Roland Barthes argues that the proleptic edge of such a "faille" (or fault) is a seam, "mobile, blank (ready to assume any contours), which is never anything but the site of its effect: the place where the death of language is glimpsed" (6).

Sullivan draws on Barthes's assertion in her interpretation of "Cormac McCarthy and the Text ofjouissance" (1995). "If, as Barthes suggests, the textof jouissance represents the seam between culture and its destruction, then Blood Meridian [1985]," believes Sullivan, "is the 'text of jouissance' par excellence, since it portrays civilization at the meridian." Cole, Rawlins, and Blevins's silent fording of the river in All the Pretty Horses supports Sullivan's general argument at the level of character delineation. At either critical level, however, presence reveals absence; "by extension," as Sullivan reasons, "nothing will be found lacking in a narrative voice until some other voice contests, creating a rupture in which silence, however momentary, marks an absence, poses a question, or plants suspicion" (120). This silent rupture in All the Pretty Horses, this momentary rapture of rebirth for the three young cowboys, accords with Sullivan's wider suggestion that McCarthy's texts of jouissance "are figurations of a provocative desire which reveals 
glimpses of what Lacan calls the 'want-to-be' (manque-à-être), our own powerful, unassuageable desire or lack" (122).

Although the presencing of the young cowboys begins on the southern side of the river, a sense of haunting still follows them. If "Little Sister Death," in the guise of "a little dirt girl with eyes like a toy bear's and two patent-leather pigtails" (972), stalks Quentin Compson in William Faulkner's The Sound and the Fury (1929), then Jimmy Blevins, who is "double bred for death by fire" (68), is "Little Brother Death" to Cole and Rawlins. "Many of the trials John Grady endures," as Luce observes, "derive from Jimmy Blevins" (62). Blevins's unexpected separation from his companions, which frees the teenagers of responsibility for their younger charge, appears to discount this omen, but this reassurance will prove short-lived. In the meantime, work on Don Héctor Rocha's ranch answers Cole and Rawlins's desires, their horse-wrangling skills appearing to seal the success of their Mexican relocation. The name of this ranch, La Hacienda de Nuestra Señora de la Purísima Concepción, appears to confirm Cole's immaculate rebirth, and he and Rawlins are immediately at home with what Phillip A. Snyder identifies as the binary construct of cowboy culture in which "independence/ integration" (203) represents the duality of self-sufficiency and teamwork. Impressing Don Héctor as an aficionado, however, Cole's horsemanship both reveals and facilitates his continued search for jouissance. This need, which is critical in comparison to Rawlins's correspondingly muted desire, finds twofold satisfaction on the ranch. In a general sense, Mexico succeeds as Cole's maternal Other, but in a specific sense, the Padron's daughter, Alejandra, manifests the female Other of his dreams. Alejandra becomes a libidinal object, an object of Cole's jouissance, a presence that stills his latent anxiety. Cole's permanent admittance to the territory of Mexican signification appears imminent.

"For Lacan," writes James D. Lilley, "speech enables us to vocalize our desire for the Mother, to establish an artificial linguistic order in the empty middle ground between ourselves and the absent Mother's womb" (278). La Purísima, which Linda Woodson calls a self-contained "discourse community" (151), seems to offer Cole the chance to fulfill his ultimate aim: a satisfactory entrance into the symbolic realm of language. McCarthy's unmarked use of Spanish in an English novel-the occurrence of non-italicized foreign words that are not explicitly translated into the host languageinevitably increase as Cole immerses himself in the discourse community at Don Héctor's ranch. In an analogy to the physical border between Texas and Mexico, with its implications of rebirth, la Purísima appears to bear Cole into what Kremlterms McCarthy's novelistic "world of permeable borders between languages" (44). Nevertheless, as Lilley notes, "we can only approximate an encounter with the real, bouncing our ineffectual language off of its surface [...] in a vain attempt to establish a connection with, and domination over, our surroundings" (278-79). Cole, the aficionado, successfully breaks horses, but the equine locus is the real, not the symbolic. "ForLacan," agrees Lilley, "the real represents the underlying, inarticulable nature of reality figured by the Mother's position in the Oedipal triangle" (278). Cole's attempt to break in(to) this particular aspect of primary reality necessarily redounds on him.

"Analysis has shown us," states Lacan in "In Memory of Ernest Jones" (1959), "that it is with images that captivate his eros as a living individual that the subject manages to ensure his implication in the signifying sequence" (595). The sight of Alejandra captivates Cole's formative sense of eroticized meaning, but man-child that he is, Cole 
initially signals his responsive desire through a third party. "Their courtship is a mutual seduction and a not altogether loving contest of wills marked by their riding in turns the lathered stallion hot from his covering the mares. John Grady rides the horse," notes Luce, "because it gives him the illusion of potencyboth in the sense of control and in the sexual sense" (59). Cole bolsters this fantasy with his recourse to the Spanish language. "Soy comandante de las yeguas," he tells the stallion, "yo y yo sólo" (128). His subsequent affair with Alejandra seemingly attests to Cole's successful arrogation of the stallion's potency, but "I am the commander of mares, I and I alone," is a statement that Alejandra's vitality will explode. For, as Lacan states about the general case, and as previously noted about Cole, "the human individual is not without presenting some indulgence toward this fragmentation of his images" (595).

One night, on riding back to the ranch from the western mesa, John Grady and Alejandra come to a lake. Indulging specular disintegration, Cole first disrobes before walking out into the water, which is "so dark" that his mirror image disappears completely. He turns his gaze to the "so pale, so pale" (141) Alejandra, who is still on the shore, to embody the fluidly maternal (amniotic) embrace he seeks. Cole has psychosomatically split and inverted his desire. His own body is lost in the dark subliminal water, while the pale female form of the littoral Alejandra reflects his willful need. Alejandra then echoes Cole's process of specular fragmentation: first, she disrobes, "like a chrysalis emerging" (141); second, she enters the water, leaving part of her (Lacanian real) self on the shore. Significantly, however, "it is not the connections of need, from whichthese images are detached, that sustain their perpetuated impact; rather," as Lacan maintains, "it is the articulated sequence in which they are inscribed that structures their insistence as signifying. This is why, sexual demand," avows Lacan, "assuming it need but present itself orally, 'ectopizes' images of introjection into the field of 'genital' desire" (595). In effect, Alejandra's immersion in the lake fulfils Cole's fragmentary desire, which presents him to Alejandra in easily consumable pieces. Their subsequent sexual encountersrealize this psychological state of affairs.

"When she comes to Cole's bed in the bunkhouse on nine consecutive nights," observes Gail Moore Morrison, Alejandra "is more overtly the aggressor in the consummation of their romance" (181). He penetrates her, but she consumes him. In "drawing blood with her teeth where he had held the heel of his hand against her mouth that she not cry out" (142), as if she were eating Cole, Alejandra enacts a form of assimilation. This female Other tries to absorb her male partner into the symbolic. Alejandra's attempt, however, is bound to fail. On the one hand, she cannot heal the tuché of Cole's primary relationship with the maternal Other, because the "not-all" female aura embraces all women. On the other hand, Cole's feelings for Alejandra are an ontological expression, which not only acknowledges jouissance as the one phenomenon of worth, but also links his overriding desire to a manque-à-être, or absence of being. "Not all of the subject can be present in the Other," affirms Laurent. "There is always a remainder" ("Alienation and Separation [I]" 24). A myth, as Lacan insists, drives the pursuit of one's sexual complement: "that it is the other, one's sexual other half, that the living being seeks in love" (205).

Alejandra's great-aunt, Dueña Alfonsa, recognizes the strength of Cole's sexual immersion, but warns him of her nephew's inflexible protection of Alejandra. If Cole does not forsake Alejandra, then Don Héctor will permanently separate them. Alfonsa places this prospect before Cole by ludic means. She invites him to play chess and intends the resultant match to indicate the hidden dangers threatening the young 
couple's game of love. That a woman is in command of the chessboard, which is a cultural anomaly, should counsel Cole to heed her advice. ${ }^{4}$ Alfonsa's lesson plays out over three rounds as she explicitly advises Cole to respect Mexican propriety concerning certain types of miscegenation. "Their chess games," writes Snyder, "serve as an obvious symbolic counterpart to their conversations, which fluctuate continuously along the rivalry/respect border and reflect Alfonsa's superiority in determining the most effective overall strategy" (217). In this elaborate fort-da variation, Cole projects his pieces into the shared territory of the chessboard, and Alfonsa becomes another of his surrogate mothers. She lets Cole win their first two games, but these defeats are part of an assessment phase, and when the crucial moment comes in the third encounter, Alfonsa is victorious. La Dueña, or "the woman in charge," loses the match by two points to one, but wins the competition, because only the last round counts in this situation. Hence, just as their contest goes from two endgames in which "he took her queen" and "she conceded and smiled her compliments" (133) to one in which "he lost his queen and conceded" (134), so Cole should admit defeat in his courtship of "Queen" Alejandra.

Alfonsa tells him in the parallel linguistic game that Mexican men never forgive their women. Don Héctor will protect his daughter from breaking the taboo on miscegenation because he at once respects and suppresses his women. The female sex "is very important in Mexico," but "women do not even have the vote" (230). The sexual division of labor on Don Héctor's ranch, as Dueña Alfonsa appreciates, echoes this environing situation. She knows the soundness of her advice: her own masculinity, the revolutionary fervor she exhibited in her youth, has left her an isolated and lonely figure. That she lost two fingers when a gun exploded in her young hand signals a reproof of gender crossing. "A man may lose his honor and regain it again," she explains. "But a woman cannot." Cole ventures to comment: "I guess I'd have to say that that don't seem right." Dueña Alfonsa, however, insists: "I am the one who gets to say" (137). ${ }^{6}$ "She is reminded that with John Grady she is speaking to a child," as Luce observes, "and one of an alien culture to boot; alien despite his fluent Spanish and his experience with his family's Mexican American workers" (61).

As his sangfroid intimates, Cole gains some unconscious satisfaction from his chess games with Alfonsa, which echo the fort-da exercise of his infancy, but he fails to appreciate Dueña Alfonsa's lesson. A strategy of unconsummated courtship, with its sense of chivalry, would better serve Cole's amatory goal than the strategy of selfish exploitation by which the Padron reads the young American's precipitant actions; gradu mutato, colonial supposition rather than deference to Mexican standards seeds Cole's downfall in Don Héctor's estimation. Alfonsa's winning strategy at chess, which points to Cole's underdeveloped psyche, and presages the risk he runs against the Padron, is one that the impaired bonding of the young man's familial circumstances denied him as a child, one that he had "never seen before," one that is called "the King's Own opening" (134). The king in this part of the continent is Mexican-and the maternal Other must respond to his call.

Cole's treatment at the hands of Dueña Alfonsa, which is little short of a psychoanalytical session, fails. Worse, her strategy has the unintentional effect of fixating Cole on his embodiment of jouissance, Alejandra; in consequence, he fails to read Don Héctor's subsequent ludic warning. "Do you play billiards?" asks the Padron. "Yessir. Some. Pool anyways." They enter "a darkened room" that smells of "must and old wood." The slate was so "crooked" last time Don Héctor played that he had 
"asked Carlos if he could make the table more level" (143). The servant's efforts seem to have succeeded and, as the Padron pots ball after ball, he slowly turns the conversation to Dueña Alfonsa's surprise suggestion that Alejandra sojourn in France. Don Héctor does not wish to banish his daughter to a place beyond his control. The French plan, he tells Cole, is one of Dueña Alfonsa's strange notions, a vestige of her own education "in Europe" (145). Although he does not say as much, Cole's departure is the Padron's preferred solution to Alejandra's waywardness. If the young man will not leave of his own accord, then Don Héctor will have him forcibly removed, but in an untraceable manner. This alternative solution prefigures violent action. The Padron now bends to pot another ball, but misses. "There," he tells his young opponent. "You see? You see how this is bad for one's billiard game? This thinking? The French"-and, by implication, all colonialists, including American cowboys-"have come into my house to mutilate my billiard game? No evil is beyond them" (146). Within days, the Mexican authorities arrest Cole and Rawlins, and now the augury of Blevins's earlier presence as "Little Brother Death" comes to pass: custody briefly reunites the three Americans, torture and probably rape precede Blevins's murder, and imprisonment at Saltillo faces Cole and Rawlins. Eventually, after both teenagers have been severely injured in violent confrontations with other inmates-the Padron's sense of mutilation finding the expression he foresaw if Cole failed to heed his ludic warning-Dueña Alfonsa pays for their release.

Rawlins immediately returns to America, but Cole does not accompany him. Mexico having let Cole down where America had previously failed, his "good mother" revealing her identity as another "bad mother," the reanimation of Cole's tuché now motivates him. His murder of the army captain who murdered Blevins and who illtreated both Cole and Rawlins results from this psychic trigger. Cole's final mastery of the captain, and his closure of their unpleasant interrelationship, is not an expression of sated revenge-that mooted explanation in Beyond the Pleasure Principle of the fort-da exercise-but a deep engagement with the interrelated systems of order and discourse that surround Cole. The young cowboy has finally realized his own transition into the symbolic realm, which his disrupted mirror imaging had retarded, and which had required a violent psychological impulse to effect. His desire, in accordance with Lacan's thesis in "The Function and Field of Speech and Language in Psychoanalysis" (1953), has become "like the desire of another, of an alter ego who dominates him and whose object of desire is henceforth his own affliction." The subject's "action destroys the object that it causes to appear and disappear by bringing about its absence and presence in advance. His action," reasons Lacan, "thus negativizes the force field of desire in order to become its own object to itself." In addressing an abstract concept, such as Mexico, or a tangible subject, such as the Mexican army captain, Cole unconsciously acknowledges that this object "obeys the negativity of his discourse." Obedience causes this potential partner to fade away; as a result, the subject seeks "to bring about the reversal that brings the partner back to his desire through a banishing summons." In short, as Lacan explains, "the symbol first manifests itself as the killing of the thing, and this death results in the endless perpetuation of the subject's desire" (262). Cole "releases" the captain one evening-Cole "cuffed the captain's bracelets through the wooden stirrups and told him he was free to go as far as he thought he could carry the saddle" (280)-but, as if loyal to a banishing summons, as if psychologically trapped between going and coming, Cole's companion has not moved by morning. In another turnabout, however, three "hombres del pais" (281), who 
appear overnight out of nowhere, take the captain in hand. These dubious characters relieve Cole of his responsibility for the captain and so release him from the grasp of maternal Mexico.

Cole's return to America on the psychological rebound repeats and reverses his initial attempt to escape a bad mother. He again crosses the Mexican-American river boundary "mounted up naked" (286), but this time he is traveling north, and this time the symbolism of rebirth signals his passage through the Oedipus complex: Cole's father is dead-no one need tell Cole this, he has felt it for some time, and one morning "when he woke he realized that he knew" (283)-and the teenager reenters America. This sorely tried representative of cowboy culture is the sole member of the Cole genealogy. He is no longer the junior Cole; yet, John Grady's arrival in Texas coincides with the funeral of Abuela, his sometime surrogate mother, and his actions at her graveside confirm the internal schism that continues to affect him. "He called her his abuela," as if his maternal grandmother by blood had been a genealogical interloperfor Abuela was "his" Luisa's mother-"and he said goodbye to her in Spanish," his bilingualism still resounding to his formative psychological split. "Lacan helps at this point," admits Tebbetts. "John Grady's loss on the ranch, his dispossession, along with his mother's abandonment of him and his abuela's death, may well capture his irrevocable separation from the feminine. His father's and grandfather's deaths and his expulsion by Alejandra's father," concludes Tebbetts, "capture the failure of the Father's symbolic order, in which he finds himself to have no place" (54-55).

Appropriately, then, when Cole walks through the cemetery of abuela's burial, he passes "the little headstones and their small remembrances," including "a chipped milkglass vase," noting on his way, "the names he knew or had known," including "Villareal" (300). Cole has traveled far in his search for an authentic (or "real") place (or "villa") to live, but his mirror imaging remains flawed (or "chipped"). While McCarthy's view of the American continent "is thoroughly postlapsarian and thoroughly undifferentiated" (301), as Blair contends, Cole fails to awaken to this environment. "Cole is," as Blair maintains, "a remnant himself, anachronistic." Even so, that remnant is not, as Blair believes, "whole within himself" (307). The repetition and reversal of immigration, signaling the autotelic nature of human desire in general, does little to fulfill Cole's need of jouissance. A child is the obscure object of maternal desire, and any suffering under this objectification is crucial to the understanding and treatment of resultant psychoses. McCarthy's figuration of John Grady Cole in All the Pretty Horses exemplifies this Lacanian lesson. Neither motherland-neither America not Mexico-wants to mother the cowboy. Cole remains, as Fisher-Wirth notes, "in almost ceaseless motion" (119). The shifting, fading, reappearing, but ultimately dissolving figure of maternity inculcates Cole with a feeling for what Terri Witek terms McCarthy's canonic leitmotif of "the impermanence of domestic spaces" (140). Cole, as a psychological subject spiraling into an autotelic mise-en-abyme of unsatisfactory substitutes for the unrealizable state of the (Lacanian) real, begins to fade from the awareness of Others.

In McCarthy's vision of postwar America, the descendents of the original Americans-tribal peoples who have almost faded from the scene owing to the colonialism that expropriated their motherland-are the only individuals who can experience Cole's kind of disappearance. Thus, the scene through which Cole rides at Iraan, Texas, plays out like a split-screen movie. On one side, there is a field of oil derricks, and on the other side, "indians camped on the western plain." The people in 
this scene, implies McCarthy, are anachronisms. "The indians stood watching him. He could see that none of them spoke among themselves or commented on his riding there nor did they raise a hand in greeting or call out to him" (301). This scene recalls the opening incident in which Cole envisioned the Comanche's passing. In this instance, however, the figures merge in mirroring each other: "now he is they," as Tebbetts recognizes, "a transient with no place his home" (57). These indigenes share Cole's fate. "They stood and watched him pass and watched him vanish upon that landscape solely because he was passing. Solely because he would vanish" (301).

According to Cawelti, "McCarthy evokes that mythical Western scene of the hero riding off into the sunset," knowing that for Cole "there is no more mythical world to cross over into" (116), there is only the forbidding prospect of American industrial and political might. From Cawelti's perspective, Cole's itinerancy has been costly; in effect, the wandering cowboy has paid the psychological price for the end of an era: "horse and rider and horse," as McCarthy delineates, "passed on and their long shadows passed in tandem like the shadow of a single being. Passed and paled into the darkening land, the world to come" (302). Moreover, as Morrison rightly states, Cole's journey "is a poignant and sobering rite of passage that leaves him still adrift in time and space." For Morrison, Cole faces a "somber vision of what is to come" (179), which leaves him in limbo, but more accurately adduced, Cole remains a chronotope apart because he remains a psychologically fractured subject. Mexico cannot supplant America as Cole's all-powerful Other, but America has forsaken him and his kind for its postwar role as a superpower.

Beyond and behind this summation, confirming while supplementing Cawelti's interpretation, however, is McCarthy's implementation of the Lacanian understanding of aphanisis. In contrast to Jones's focus on the capacity for sexual enjoyment, Lacan's definition of aphanisis in "The Subversion of the Subject and the Dialectic of Desire in the Freudian Unconscious" (1960) concerns the "fading' or eclipse of the subject that is closely bound up with the Spaltung": the subject "suffers from its subordination to the signifier" (686). As Armine Kotin Mortimer explains, "the repressed subject appears only in the fading of the enunciation" (62), and this elision, as Barthes proposes in $\mathrm{S} / \mathrm{Z}$ (1970), "enables the utterance to shift from one point of view to another" (41-42). Thus, as Lacan contends, "when the subject appears somewhere as meaning, he is manifested elsewhere as 'fading,' as disappearance" (218). In Cole's case, loyalty to an identity that others deem manifestly timeworn obscures the subject behind his chosen signifier: "cowboy," where Cole is concerned, "indian," where Cole's observers are concerned. What is more, as Mortimer insists, "just like the voice of the subject in psychoanalysis, whose origin is unretrievable, the discourse in the plural textespecially in the modern text-is subject to fading at the moment of rapture, and then culture, the other edge, returns. It is that very hole in its discourse that the modern text seeks as rapture, not the violence of rupture" (62).

In the final analysis, then, McCarthy affords John Grady Cole his period of rapture. The isolated cowboy figuratively fades away at the end of All the Pretty Horses; this selfimposed aphanisis is the opening rupture of his rapturous nonappearance in the second part of the Border Trilogy, The Crossing (1994); and this rapture ends violently with Cole's murder in the urban squalor of Cities of the Plain (1998), the novel that closes McCarthy's trilogy. 


\section{BIBLIOGRAPHY}

Arnold, Edwin T. “'Go to Sleep': Dreams and Visions.” A Cormac McCarthy Companion: The Border Trilogy. Ed. Edwin T. Arnold and Dianne C. Luce. Jackson, MS: UP of Mississippi, 2001. 37-72. Print.

Barthes, Roland. The Pleasure of the Text. 1973. Trans. Richard Miller. New York: Hill and Wang, 1974. Print.

---. S/Z. Trans. Richard Miller. New York: Hill and Wang, 1974. Print.

Bell, Vereen. "'Between the Wish and the Thing the World Lies Waiting." Southern Review 28.4 (1992): 920-27. Print.

Blair, John. "Mexico and the Borderlands in Cormac McCarthy's All the Pretty Horses." Critique 42.3 (2001): 301-7. Print.

Bowman, James. Honor: A History. New York: Encounter, 2007. Print.

Brenkman, John. Culture and Domination. Ithaca, NY: Cornell UP, 1987. Print.

Bronowski, Jacob. The Ascent of Man. London: Random, 2011. Print.

Cawelti, John G. The Six-Gun Mystique. 1970. Bowling Green, OH: Bowling Green State U Popular P, 1984. Print.

Dor, Joël. Introduction to the Reading of Lacan: The Unconscious Structured like a Language. Ed. Judith Feher Gurewich and Susan Fairfield. Northvale, NJ: Aronson, 1997. Print.

Ellis, Jay. "Fetish and Collapse in No Country for Old Men." Cormac McCarthy. Ed. Harold Bloom. New York: Infobase, 2009. 133-70. Print.

Faulkner, William. The Sound and the Fury. 1929. William Faulkner Novels 1926-1929: Soldiers' Pay, Mosquitoes, Sartoris, The Sound and the Fury. Ed. Joseph Blotner and Noel Polk. New York: Library of America, 2006. 877-1124. Print.

Fisher-Wirth, Ann. "El Otro Sud: Willa Cather and Cormac McCarthy." Value and Vision in American Literature: Literary Essays in Honor of Ray Lewis White. Ed. Joseph Candido. Athens: Ohio UP, 1999. 115-31. Print.

Freud, Sigmund. Beyond the Pleasure Principle. 1920. The Standard Edition of the Complete Psychological Works of Sigmund Freud. Trans. and ed. James Strachey. Vol. 18. London: Hogarth, 1961. Print.

Hage, Erik. Cormac McCarthy: A Literary Companion. Jefferson, NC: Farland, 2010. Print. Heidegger, Martin. “Building, Dwelling, Thinking." 1951. Poetry, Language, Thought. Trans. Albert Hofstadter. New York: Harper, 2001. 141-60. Print.

Jones, Ernest. "Early Development of Female Sexuality." 1927. Psychoanalysis and Female Sexuality. Ed. Hendrik Marinus Ruitenbeek. New Haven, CT : College and UP Services, 1966. 2135. Print.

Karpman, Ben. "The Psychology of Chess." The Psychoanalytic Review: An American Journal of Psychoanalysis 24 (1937): 54-69. Print. 
Kreml, Nancy. "Implicatures of Styleswitching in the Narrative Voice of Cormac McCarthy's All the Pretty Horses." Codes and Consequences: Choosing Linguistic Varieties. Ed. Carol Myers-Scotton. Oxford, UK: Oxford UP, 1998. 41-61. Print.

Lacan, Jacques. "The Agency of the Letter in the Unconscious or Reason since Freud." 1957.

Ecrits: The First Complete Edition in English. Trans. Bruce Fink, Héloïse Fink, and Russell Grigg. New York: Norton, 2006. 161-97. Print.

---. "The Direction of the Treatment and the Principles of its Power." 1958. Ecrits: The First Complete Edition in English. Trans. Bruce Fink, Héloïse Fink, and Russell Grigg. New York: Norton, 2006. 489-542. Print.

---. The Four Fundamental Concepts of Psycho-Analysis. Trans. Alan Sheridan. Ed. Jacques-Alain Miller. London: Penguin, 1977. Print.

---. "The Function and Field of Speech and Language in Psychoanalysis." 1953. Ecrits: The First Complete Edition in English. Trans. Bruce Fink, Héloïse Fink, and Russell Grigg. New York: Norton, 2006. 197-268. Print.

---. "In Memory of Ernest Jones: On His Theory of Symbolism." 1959. Ecrits: The First Complete Edition in English. Trans. Bruce Fink, Héloïse Fink, and Russell Grigg. New York: Norton, 2006. 585-601. Print.

---. "The Subversion of the Subject and the Dialectic of Desire in the Freudian Unconscious." 1960. Ecrits: A Selection. Trans. Alan Sheridan. London: Routledge, 2012. 223-49. Print.

Laurent, Éric. “Alienation and Separation (I).” Reading Seminar XI: Lacan's Four Fundamental Concepts of Psychoanalysis: Including the First English Translation of 'Position of the Unconscious' by Jacques Lacan. Ed. Richard Feldstein, Bruce Fink, and Maire Jaanus. Albany, NY: State U of New York P, 1995. 19-28. Print.

---. “Alienation and Separation (II)." Reading Seminar XI: Lacan's Four Fundamental Concepts of Psychoanalysis: Including the First English Translation of 'Position of the Unconscious' by Jacques Lacan. Ed. Richard Feldstein, Bruce Fink, and Maire Jaanus. Albany, NY: State U of New York P, 1995. 29-38. Print.

Lilley, James D. “'The hands of yet other puppets': Figuring Freedom and Reading Repetition in All the Pretty Horses." Myth, Legend, Dust: Critical Responses to Cormac McCarthy. Ed. Rick Wallach. Manchester, UK: Manchester UP, 2000. 272-87. Print.

Luce, Dianne C. “'When You Wake': John Grady Cole's Heroism inAll the Pretty Horses.” Sacred Violence: Essays from the First Cormac McCarthy Conference. Ed. Wade Hall and Rick Wallach. 2 vols. Vol. 2: Cormac McCarthy's Western Novels. El Paso, TX: Texas Western P, 1995. 57-70. Print.

McCarthy, Cormac. All the Pretty Horses. New York: Picador, 1993. Print.

Mellard, James M. UsingLacan, Reading Fiction. Urbana, IL: U of Illinois P, 1991. Print.

Morrison, Gail Moore. “All the Pretty Horses: John Grady Cole's Expulsion from Paradise.” Perspectives on Cormac McCarthy. Ed. Edwin T. Arnold and Dianne C. Luce. Jackson: UP of Mississippi, 1999. 175-94. Print.

Mortimer, Armine Kotin. The Gentlest Law: Roland Barthes's The Pleasure of the Text. New York: Lang, 1989. Print.

Ragland-Sullivan, Ellie. Jacques Lacan and the Philosophy of Psychoanalysis. Urbana, IL: U of Illinois P, 1986. Print. 
Snyder, Phillip A. “Cowboy Codes in Cormac McCarthy's Border Trilogy.” A Cormac McCarthy Companion: The Border Trilogy. Ed. Edwin T. Arnold and Dianne C. Luce. Jackson: UP of Mississippi, 2001. 198-227. Print.

Sullivan, Nell. "Cormac McCarthy and the Text of Jouissance." Sacred Violence: A Reader's Companion to Cormac McCarthy. Ed. Wade Hall and Rick Wallach. El Paso, TX: U of Texas P, 1995. 115-23. Print.

Tatum, Stephen. Cormac McCarthy's All the Pretty Horses: A Reader's Guide. New York: Continuum International, 2002. Print.

Tebbetts, Terrell L. “In Conflict with Himself: John Grady's Quest in All the Pretty Horses." Philological Review 27.2 (2001): 37-58. Print.

Witek, Terri. “Reeds and Hides: Cormac McCarthy's Domestic Spaces." Southern Review 30.1

(1994): 136-42. Print.

Woodson, Linda. "Deceiving the Will to Truth: The Semiotic Foundation of All the Pretty Horses." Sacred Violence: Essays from the First Cormac McCarthy Conference. Ed. Wade Hall and Rick Wallach. 2 vols. Vol. 2: Cormac McCarthy's Western Novels. El Paso, TX: Texas Western P, 1995. 149-54. Print.

\section{NOTES}

1. With reference to Freud and Carl Jung, Arnold traces the psychological hunger of McCarthy's southern protagonists, and argues that these characters' "intense feelings and fears and conflicts" are "nowhere [...] more clearly revealed than in their dreams" (39). In his analysis of No Country for Old Men (2005), Jay Ellis draws briefly on the "primeval scene around a fire" (160) from Freud's Civilization and its Discontents (1930), but soon turns to the notion of "Jungian individuation" (161).

2. James D. Lilley and Terrell L. Tebbetts are other exceptions to the rule, but their forays into Lacanian psychoanalysis are even briefer than Sullivan's is.

3. "Faulkner," chronicles Erik Hage, "was such an important influence on McCarthy's early novels" (97), and has remained a source of inspiration.

4. "Although there have been ladies' international tournaments," as Benjamin Karpman observes, "women don't take avidly to chess" (69).

5. Ironically, however, and as her courage in warning Cole further attests, Alfonsa's ability at chess confirms that Mexican society has failed to extinguish her nonconformity.

6. "Even the charros at the ranch," as Woodson remarks, "speak to John Grady about the difficulty of living in a discourse community whose truth is not one's own" (152).

\section{ABSTRACTS}

This article uses Jacques Lacan's reading of the Freudian fort-dagame to analyze that most American of cultural constructs, the cowboy, at the time of that figure's fading from the American landscape: the immediate postwar years. With John Grady Cole, the protagonist of All 
the Pretty Horses (1992), Cormac McCarthy provides a suitably situated subject for this critical endeavor, one whose subjective characteristics become present through dramatically playful division of his maternal imago. These games of psychoanalytical maturation, which emerge from the alternation between psychoanalysis in theory and that theory in critical practice, and which trace their subject's successive relocations to alternative sides of the American-Mexican border, articulate the inevitable though resisted diminishment of Cole's cultural construction.

\section{INDEX}

Mots-clés: Cormac McCarthy, Lacan Jacques, Sigmund Freud

Keywords: aphanisis, fort-da, games, jouissance, psychoanalysis, Spaltung

\section{AUTHOR}

\section{MICHAEL WAINWRIGHT}

Royal Holloway, University of London 